\title{
Karakteristik Minuman Probiotik Sari Ubi Kayu dari Kultur Bakteri Lactobacillus acidophilus dan Streptococcus thermophilus
}

\author{
Characteristics of Cassava Probiotik Drinks of Lactobacillus acidophilus and \\ Streptococcus thermophilus Culture
}

\author{
Nunung Yulia*, Adi Wibowo, Eva Dania Kosasih \\ Jurusan Farmasi, Politeknik Kesehatan Kemenkes Tasikmalaya, Kota Tasikmalaya, Indonesia \\ *E-mail:nungyulia86@gmail.com
}

Diterima : 25 November 2019

Direvisi:30 Mei 2020

Disetujui: 16 Juni 2020

\begin{abstract}
Abstrak
Pangan fungsional merupakan pangan yang dikonsumsi sebagai makanan biasa yang memiliki manfaat fisiologis dan dapat mengurangi efek dari penyakit kronis. Salah satu produk pangan fungsional yang banyak dikonsumsi adalah minuman probiotik. Minuman probiotik yang dikenal masyarakat selama ini merupakan hasil fermentasi susu sapi sehingga relatif mahal harganya. Pemanfaatan bahan baku alternatif seperti sari ubi kayu diperlukan untuk menghasilkan produk minuman probiotik yang lebih terjangkau dan memiliki kualitas yang baik. Tujuan penelitian ini untuk mengetahui pengaruh perbandingan kultur terhadap karakteristik minuman probiotik dan mendapatkan perbandingan kultur terbaik yang menghasilkan karakteristik probiotik terbaik dari minuman probiotik sari ubi kayu. Penelitian ini menggunakan metode deskriptif kualitatif dengan jenis bakteri Lactobacillus acidophilus dan Streptococcus thermophilus sebagai inokulum uji. Kultur bakteri dibuat seri perbandingan dengan sari ubi kayu yaitu 20:50, 30:50, 40:50, dan 50:50. Pengujian karakteristik yang diamati adalah nilai $\mathrm{pH}$, viskositas, total bakteri asam laktat (BAL) dan uji aktivitas terhadap bakteri Escherichia coli. Hasil penelitian menujukkan bahwa perbandingan kultur dengan sari ubi kayu terbaik yang menghasilkan minuman probiotik yang memenuhi syarat sebagai kriteria probiotik adalah 50:50 dengan nilai $\mathrm{pH}$ yaitu 4,1; viskositas yaitu $0,706 \mathrm{~g} / \mathrm{mL}$; total bakteri asam laktat (BAL) yaitu $2,1 \times 10^{6} \mathrm{cfu} / \mathrm{mL}$; dan aktivitas terhadap bakteri Escherichia coli yaitu 5,3 mm.
\end{abstract}

Kata kunci : Minuman probiotik; Ubi kayu; Lactobacillus acidophilus; Streptococcus thermophilus

\begin{abstract}
Functional foods are food that consumed, as usual, has a physiological effect and can reduce the effect of chronic disease. One of them is probiotic beverages. Probiotic beverages that have been widely known overtime was produced by a dairy house. This product could have been expensive due to the cost of raw materials. The alternative raw material such as the use of extracted cassava juice may reduce the price of the final product. The aims of this research were to study the effects of culture comparison between characteristics of the probiotic beverage from cassava juice, and get the best culture comparison that produces the best probiotic characteristics of the lactic beverage fermentation from cassava juice. This research applied qualitative experiment method in Lactobacillus acidophilus and Streptococcus thermophiles as an inoculum evaluated. Serial in culture ratio respectively 20:50; 30:50; 40:50; and 50:50. The observed research were $p H$ value, viscosity, total lactic acid bacteria (LAB) and activities test against bacteria Escherichia coli. The result showed that the best culture comparison qualified as probiotics criteria was 50:50. It was having pH value 4,1; viscosity 0,706 g/mL; total LAB 2,1x106 cfu/mL and activity bacteria Escherichia coli was 5,3 mm.
\end{abstract}

Keywords: Probiotic drinks; Cassava; Lactobacillus acidophilus; Streptococcus thermophilus 


\section{PENDAHULUAN}

Kemajuan di bidang teknologi memberikan dampak terhadap perubahan gaya hidup dan pola makan di masyarakat. Pola makan modern melalui konsumsi bahan makanan tinggi lemak dan rendah serat merupakan salah satu pemicu munculnya berbagai macam penyakit yang berhubungan dengan saluran pencernaan. Kondisi ini membuat masyarakat menyadari akan pentingnya memilih makanan dan minuman yang tidak hanya menyediakan zat gizi namun juga memberikan pengaruh baik bagi kesehatan. ${ }^{1}$

Pangan fungsional merupakan pangan yang secara alamiah maupun telah mengalami proses, memiliki satu atau lebih senyawa yang berdasarkan kajian ilmiah dianggap memiliki fungsi fisiologis tertentu yang bermanfaat bagi kesehatan. ${ }^{2}$ Salah satu produk pangan fungsional yang sering dikonsumsi yaitu minuman probiotik. Minuman probiotik adalah minuman yang mengandung bakteri asam laktat (BAL) yang menguntungkan bagi saluran pencernaan. Produk probiotik dapat menghambat bakteri patogen dan selain mempunyai nilai nutrisi yang baik, produk tersebut dianggap memberi manfaat kesehatan dan terapeutik. Manfaat ini diperoleh akibat terbawanya bakteribakteri hidup ke dalam saluran pencernaan yang mampu memperbaiki komposisi mikroflora usus sehingga mengarah pada dominansi bakteri-bakteri yang menguntungkan kesehatan. ${ }^{3}$

Salah satu bakteri asam laktat yang sering digunakan dalam pembuatan minuman probiotik yaitu Lactobacillus yang memiliki kemampuan meningkatkan pertahanan imunitas non-spesifik. ${ }^{4}$ Lactobacillus menggunakan karbohidrat sebagai sumber energi dan memproduksi asam laktat sebagai produk utama dari hasil metabolismenya. Spesies Lactobacillus yang biasa digunakan dalam proses fermentasi yoghurt yaitu Lactobacillus acidophilus yang bersifat homofermentatif yakni dalam jalur glikolisis menghasilkan hanya berupa asam laktat dan diketahui dapat meningkatkan produksi makrofag dan mengaktifkan fagosit. ${ }^{5}$ Spesies lain yang dapat digunakan dalam proses fermentasi yakni Streptococcus thermophilus yang berperan sebagai probiotik, mengurangi gejala intoleransi laktosa dan gangguan gastrointestinal lainnya. Ketika digunakan sebagai kultur campuran, kedua bakteri ini bersimbiosis mutualisme, L. acidophilus dilaporkan menghasilkan asam amino dan peptida pendek yang menstimulasi pertumbuhan $S$. thermophilus, sedangkan $S$. thermophilus menghasilkan asam format yang menunjang pertumbuhan $L$. acidophilus. ${ }^{6}$

Produk probiotik yang berkembang pesat saat ini adalah produk berbasis susu sapi dengan harga yang relatif mahal, sehingga perlu digunakan bahan alternatif dari nabati sebagai bahan baku pembuatan minuman probiotik untuk memperoleh minuman probiotik yang lebih terjangkau bagi masyarakat. Minuman probiotik berbahan nabati yang sudah diteliti diantaranya minuman fermentasi laktat sari buah nanas, minuman yoghurt dari sari kulit nanas, yoghurt sinbiotik dari ekstrak cincau hijau, minuman probiotik dari sari kurma, serta minuman probiotik buah naga merah. ${ }^{7-11}$

Banyak bahan pangan yang selama ini belum dimanfaatkan secara optimal dengan potensi yang cukup tinggi untuk dijadikan minuman probiotik. Salah satu bahan pangan tersebut adalah ubi kayu. Ubi kayu memiliki potensi untuk dijadikan bahan baku pangan fungsional dalam pembuatan minuman probiotik (yoghurt) karena kandungan karbohidrat dan skopoletin sebagai komponen bioaktif yang mempunyai fungsi fisiologis bagi kesehatan. Ubi kayu juga mudah didapatkan dengan harga yang lebih murah. Sampai saat ini pemanfaatan ubi kayu sebagai pangan fungsional yang sudah diteliti diantaranya yaitu olahan ubi kayu berupa tepung dan flakes, dan pembuatan sake berbasis ubi kayu, tetapi 
pemanfaatan ubi kayu sebagai probiotik belum banyak dilaporkan., ${ }^{2,12}$ Pengembangan minuman probiotik dari ubi kayu diharapkan dapat menambah produk minuman probiotik yang bersumber dari bahan nabati. Agar dapat dihasilkan minuman probiotik yang memenuhi syarat sebagai kriteria probiotik maka pada penelitian ini diteliti mengenai karakteristik minuman probiotik sari ubi kayu dari bakteri Lactobacillus acidophilus dan Streptococcus thermophilus, sehingga diharapkan dapat ditemukan perbandingan kultur dengan sari ubi kayu yang menghasilkan karakteristik minuman probiotik terbaik.

Penelitian ini dilakukan untuk mendapatkan perbandingan kultur dengan sari ubi kayu yang menghasilkan karakteristik minuman probiotik terbaik dan mengetahui karakteristik minuman probiotik sari ubi kayu sebagai minuman probiotik.

\section{METODE}

Penelitian dilakukan pada bulan Maret 2019 sampai November 2019, bertempat di Laboratorium Biologi Farmasi Jurusan Farmasi Politeknik Kesehatan Kemenkes Tasikmalaya. Proses pembuatan produk minuman probiotik sari ubi kayu dilakukan beberapa tahapan antara lain tahapan pertama adalah tahapan pemantapan pembuatan yoghurt dengan menggunakan inokulasi campuran bakteri Lactobacillus acidophilus dan Streptococcus thermophilus, pembuatan sari ubi kayu, kedua menguji karakteristik pada minuman probiotik sari ubi kayu dan ketiga melakukan pengujian aktivitas terhadap Escherichia coli.

\section{Alat dan bahan}

Alat yang digunakan yaitu autoklaf (Labtech), inkubator (Memmert), Biosafety Cabinet (Biobase), pH meter (Hanna), Viskometer (MRC), Colony Counter, cawan petri, jarum ose, timbangan analitik, pinset, jangka sorong, hotplate, penyaring dan alat-alat gelas yang ada di laboratorium. Bahan yang digunakan yaitu ubi kayu, aquadest, susu murni, glukosa, Lactobacillus acidophilus, Streptococcus thermophile, dan Escheruchia coli, dan media MRS (Man Rogosa Sharpe) dan Media Nutrient Agar (Oxoid).

\section{Prosedur kerja}

Persiapan starter

Persiapan starter dilakukan dengan metode yang dimodifikasi. Bakteri $L$. acidophilus dan $S$. thermophilus ditumbuhkan dalam medium selektif MRS (Man Rogosa Sharpe) agar miring steril, di inkubasi suhu $37^{\circ} \mathrm{C}$, selama 24 jam. Stok kultur bakteri $L$. acidophilus dan $S$. thermophilus pada agar miring dibuat suspensi bakteri pada media MRS Broth steril. Sebanyak $40 \mu \mathrm{L}$ suspensi bakteri ditumbuhkan kedalam susu 5\% (b/v) steril $10 \mathrm{~mL}$ dan diinkubasi pada suhu $37^{\circ} \mathrm{C}$ selama 24 jam. Kultur ini disebut kultur induk. Kemudian kultur induk diinokulasikan kedalam media susu 5\% (b/v) dan glukosa 3\% (b/v) dalam media sari ubi kayu $50 \mathrm{~mL}$ dan diinkubasi pada suhu $37^{\circ} \mathrm{C}$ selama 48 jam sehingga didapat kultur antara. Selanjutnya kultur antara dibuat seri perbandingan dengan sari ubi kayu berdasarkan percobaan pendahuluan sebelumnya yaitu 20:50, 30:50, 40:50, dan 50:50 diinokulasikan sebanyak 4\% (v/v) ke dalam media susu skim $5 \%(\mathrm{~b} / \mathrm{v})$ dengan penambahan $7,5 \% \quad(\mathrm{~b} / \mathrm{v})$ glukosa dalam media sari ubi kayu $50 \mathrm{~mL}$. Inkubasi dilakukan selama 48 jam pada suhu $37^{\circ} \mathrm{C}$, sehingga didapatkan kultur kerja. ${ }^{8}$

Pembuatan minuman probiotik dari sari ubi kayu

Ubi kayu yang dipilih ialah ubi kayu untuk pangan konsumsi langsung dengan daging umbi berwarna putih. Ubi kayu dipisahkan dari kulitnya dan dihaluskan menggunakan parutan dan ditambah air, kemudian disaring dan dipisahkan dari ampasnya. Sari ubi kayu yang telah dipisahkan dari ampas selanjutnya di blanching dengan suhu $87^{\circ} \mathrm{C}$ selama 15 menit, kemudian didinginkan hingga suhu 
kamar. Setelah dingin lalu ditambahkan susu steril sebanyak $10 \%$ (v/v) dan glukosa steril 7,5\% (b/v).

Pembuatan minuman probiotik dilakukan metode yang dimodifikasi. Sari ubi kayu yang dihasilkan kemudian dilakukan fermentasi dengan penambahan kultur kerja $L$. acidophilus dan $S$. thermophilus secara aseptis. Diinkubasi pada suhu $37^{\circ} \mathrm{C}$ selama 16 jam, hingga mencapai $\mathrm{pH}$ 3,5-4. Minuman probiotik sari ubi kayu yang telah selesai di inkubasi kemudian disimpan dalam refrigerator suhu $4^{\circ} \mathrm{C}{ }^{8}$

Pengujian nilai $\mathrm{pH}$

Pengujian nilai $\mathrm{pH}$ dilakukan berdasarkan metode yang dimodifikasi. Sebelum dilakukan pengukuran, $\mathrm{pH}$ meter dikalibrasi menggunakan larutan buffer asam, netral, dan basa. Selanjutnya dilakukan pengukuran terhadap sampel yang dicelupkan dalam elektroda pada $\mathrm{pH}$ meter dan dibiarkan beberapa saat sampai diperoleh pembacaan yang stabil. ${ }^{8}$

\section{Uji viskositas}

Spindle dipasang pada lengan spindle. Spindle dimasukkan ke dalam sampel yang diuji. Motor dihidupkan sehingga spindle berputar dan jika jarum dial menunjukkan angka stabil maka motor dimatikan. Angka yang ditunjukkan oleh jarum dial dicatat dan setiap sampel diukur 5 kali kemudian diambil rata-rata. Nilai rata-rata kekentalan produk yang diuji diperoleh dari angka rata-rata dikalikan dengan faktor pengali yang sesuai dengan kecepatan dan nomor spindle yang dipakai. ${ }^{13}$

Uji total bakteri asam laktat

Pengujian total bakteri asam laktat dilakukan dengan metode yang dimodifikasi. Sampel diambil $1 \mathrm{~mL}$ dan dimasukkan dalam tabung reaksi yang berisi $9 \mathrm{~mL}$ larutan pepton steril (pengenceran $10^{-1}$ ). Selanjutnya dibuat seri pengenceran dari $10^{-1}$ sampai $10^{-5}$. Masingmasing seri pengenceran diambil $1 \mathrm{~mL}$ dan dituang kedalam cawan petri yang berisi media MRSA steril (hangat). Setelah media memadat, diinkubasi pada suhu $37^{\circ} \mathrm{C}$ selama 48 jam. Pertumbuhan koloni dicatat pada setiap cawan yang mengandung koloni. Angka Total Plate Count (TPC) dihitung dalam $1 \mathrm{~mL}$ dengan mengalikan jumlah koloni rata-rata dengan faktor pengenceran yang digunakan dengan satuan colony forming unit $/ \mathrm{mL}$ atau koloni/mL. ${ }^{8}$

\section{Perhitungan Jumlah Total Bakteri: \\ Jumlah koloni $x \frac{1}{\text { faktor pengenceran }}$}

Uji aktivitas antibakteri

Pengujian aktivitas terhadap bakteri Escherichia coli dilakukan berdasarkan metode yang dimodifikasi. Stok biakan Escherichia coli standard McFarland 0,5 diinokulasi pada media Nutrient Agar dengan teknik streaked plate. Produk minuman probiotik diteteskan pada paper disc sehingga didapatkan volume sebanyak $100 \mu \mathrm{l}$, kemudian diletakkan pada media agar yang berisi bakteri dan di inkubasi pada suhu $37^{\circ} \mathrm{C}$ selama $1-2 \times 24$ jam. Pengamatan dilakukan pada zona bening yang terbentuk di sekeliling paper disc yang merupakan zona hambatan, lalu diukur diameter terbesar dan terkecil zona. $^{6}$

\section{HASIL DAN PEMBAHASAN}

Yoghurt merupakan susu asam yang dihasilkan dari proses fermentasi susu oleh campuran bakteri asam laktat (BAL) thermophilic yang akan membentuk rasa asam, aroma yang khas serta komponenkomponen pembentuk cita rasa. Dalam pembuatan minuman probiotik (yoghurt) sari ubi kayu ini, kultur bakteri yang digunakan adalah L.acidophilus dan S.thermophilus. L.acidophilus dapat tumbuh baik dengan oksigen ataupun tanpa oksigen, bakteri ini dapat hidup pada lingkungan yang sangat asam sekalipun, seperti pada $\mathrm{pH}$ 4-5 atau dibawahnya dan bakteri ini merupakan bakteri homofermentatif yaitu bakteri yang 
memproduksi asam laktat sebagai satusatunya produk akhir. Bakteri S.thermophilus merupakan BAL homofermentatif yang menghasilkan asam laktat sebagai produk utamanya. ${ }^{14}$ Media yang digunakan untuk menumbuhkan BAL yaitu Media MRS (de Man Rogosa and Sharpe) yang merupakan media selektif bagi kedua bakteri tersebut.

Pembuatan starter dimulai dari stok kultur bakteri Lactobacillus acidophilus dan Streptococcus thermophilus yang dimasukkan kedalam media MRS Broth steril dan difermentasi pada susu sapi sebagai media. Hasil fermentasi ini disebut kultur induk. Selanjutnya dari kultur induk diinokulasikan kedalam media susu dan glukosa dalam media sari ubi kayu sehingga diperoleh kultur antara. Kultur antara dibuat seri perbandingan dengan sari ubi kayu berdasarkan uji pendahuluan sebelumnya yaitu 20:50, 30:50, 40:50, dan 50:50 dengan penambahan susu dan glukosa sehingga diperoleh kultur kerja. Hasil pembuatan kultur dapat dilihat pada Gambar 1.

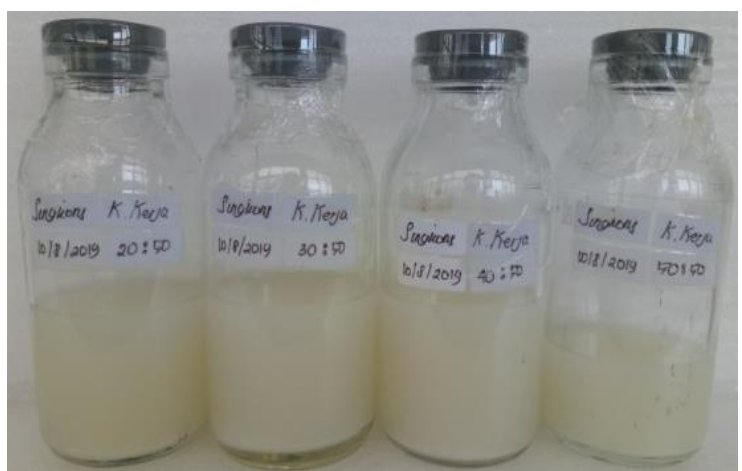

Gambar 1. Hasil kultur kerja

Sesuai dengan kebutuhan nutrisinya untuk pertumbuhan BAL selain glukosa atau karbohidrat, BAL juga memerlukan protein dan mineral. Hampir semua BAL hanya memperoleh energi dari metabolisme gula sehingga habitat pertumbuhannya hanya terbatas pada lingkungan yang menyediakan cukup gula. Untuk tetap bertahan hidup, BAL dalam pertumbuhannya memerlukan sumber nitrogen yang berupa asam amino, sumber karbon atau energi berupa glukosa, sumber vitamin berupa vitamin B dan sumber mineral berupa $\mathrm{Mg}, \mathrm{Mn}$, dan $\mathrm{S} .{ }^{15}$

Pembuatan sari ubi kayu dimulai dengan cara pemilihan ubi kayu yang baik, dan pemisahan sari dengan ampasnya. Sari ubi kayu yang didapatkan dilakukan blanching yang bertujuan untuk inaktivasi enzim dan mengurangi jumlah mikroba awal. Blanching merupakan suatu cara atau perlakuan pemanasan tipe pasteurisasi yang dilakukan pada suhu kurang dari $100^{\circ} \mathrm{C}$ selama beberapa menit, dengan menggunakan air panas atau uap. ${ }^{16}$ Sari ubi kayu yang telah blanching kemudian ditambahkan susu dan glukosa 7,5\%. Penambahan gula (sukrosa, glukosa, laktosa dan fruktosa) disamping sebagai sumber rasa manis juga merupakan sumber energi yang baik bagi mikroorganisme dalam proses perkembangbiakan. Total BAL tertinggi diperoleh produk dengan konsentrasi sukrosa 7,5\%. ${ }^{17}$ Setelah dingin dilakukan penambahan kultur bakteri Lactobacillus acidophilus dan Streptococcus thermophilus secara aseptis. Gabungan antara dua isolat bakteri akan menghasilkan asam laktat yang jumlahnya lebih tinggi dibandingkan menggunakan isolat tunggal. Dengan digunakannya dua isolat bakteri, diduga metabolit yang dihasilkan akan lebih tinggi, selain itu jumlah bakteri asam laktat akan meningkat. ${ }^{18}$ Hasil pembuatan minuman probiotik sari ubi kayu dapat dilihat pada Gambar 2.

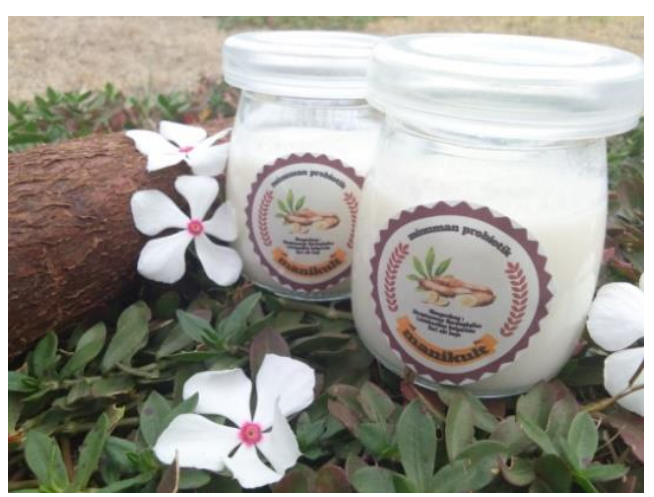

Gambar 2. Minuman probiotik sari ubi kayu 
Tabel 1. Karakteristik minuman probiotik sari ubi kayu

\begin{tabular}{lccccccc}
\hline \multirow{2}{*}{ Sampel } & \multirow{2}{*}{ pH } & \multirow{2}{*}{ Viskositas } & Total bakteri asam & \multicolumn{4}{c}{ Organoleptis } \\
\cline { 5 - 8 } & & & laktat $($ CFU/mL) & Rasa & Aroma & Tekstur & Warna \\
\hline $20: 50$ & 5,0 & $0,966 \mathrm{~g} / \mathrm{mL}$ & $8 \times 10^{4}$ & Asam & Khas & Cair & Putih \\
$30: 50$ & 4,7 & $0,873 \mathrm{~g} / \mathrm{mL}$ & $1,95 \times 10^{6}$ & Asam & Khas & Cair & Putih \\
$40: 50$ & 4,3 & $0,742 \mathrm{~g} / \mathrm{mL}$ & $1,98 \times 10^{6}$ & Asam & Khas & Cair & Putih \\
$50: 50$ & 4,1 & $0,706 \mathrm{~g} / \mathrm{mL}$ & $2,10 \times 10^{6}$ & Asam & Khas & Cair & Putih \\
\hline
\end{tabular}

Karakteristik minuman probiotik meliputi pengujian $\mathrm{pH}$, viskositas, organoleptic, dan total bakteri asam laktat (BAL). Setelah diperoleh minuman probiotik dengan karakteristik yang baik kemudian dilakukan pengujian aktivitas terhadap bakteri Escherichia coli. Hasil pengujian karakteristik minuman probiotik sari ubi kayu dapat dilihat pada Tabel 1.

Berdasarkan Tabel 1, hasil pengukuran $\mathrm{pH}$ menunjukkan terjadinya perbedaan nilai $\mathrm{pH}$ pada minuman probiotik masingmasing perbandingan kultur dengan sari ubi kayu. Nilai $\mathrm{pH}$ masing-masing perbandingan sebesar $4,1-5,0$ termasuk $\mathrm{pH}$ yang cukup rendah dalam pembuatan minuman probiotik, sehingga variasi perbandingan kultur dengan sari ubi kayu pada pembuatan minuman probiotik sari ubi kayu cenderung mengalami penurunan seiring dengan konsentrasi kultur yang semakin meningkat. Hal ini disebabkan karena semakin tingginya konsentrasi kultur yang ditambahkan pada sari ubi kayu dipengaruhi oleh kemampuan starter dalam membentuk asam laktat yang digunakan atau ditentukan oleh jumlah dan jenis starter yang digunakan. ${ }^{18}$ Besar kecilnya nilai $\mathrm{pH}$ dipengaruhi oleh konsentrasi ion $\mathrm{H}^{+}$. Asam laktat yang dihasilkan selama proses fermentasi merupakan asam yang mudah terdisosiasi menjadi ion $\mathrm{H}^{+}$dan ion $\mathrm{CH}_{3} \mathrm{CHOHCOO}^{-}$. Konsentrasi ion $\mathrm{H}^{+}$yang tinggi akan menurunkan nilai $\mathrm{pH}$ sehingga minuman probiotik setelah fermentasi menjadi asam. Total asam laktat berhubungan dengan nilai $\mathrm{pH}$. Semakin tinggi nilai asam laktat yang dihasilkan, maka nilai $\mathrm{pH}$ semakin rendah. ${ }^{17}$
Adanya asam laktat dan total padatan terlarut lainnya dapat mempengaruhi viskositas produk. Pada perbandingan kultur dengan sari ubi kayu 50:50 memiliki nilai viskositas yang lebih rendah (sebesar $0,706 \mathrm{~g} / \mathrm{mL}$ ). Keberadaan asam-asam organik termasuk asam laktat sebagai metabolit bakteri asam laktat selama fermentasi merupakan salah satu komponen padatan terlarut yang dapat meningkatkan viskositas. ${ }^{19}$

Semakin tinggi konsentrasi kultur bakteri pada pembuatan minuman probiotik sari ubi kayu maka nilai total bakteri asam laktat semakin meningkat. Pada perbandingan kultur dengan sari ubi kayu 50:50 jumlah bakteri asam laktat lebih banyak sekitar $2,10 \times 10^{6} \mathrm{~g} / \mathrm{mL}$ dibandingkan dengan perbandingan lainnya. Peningkatan total bakteri asam laktat diduga terjadi akibat semakin banyak kultur bakteri. Produk yang dikatakan sebagai probiotik harus mengandung bakteri probiotik dengan jumlah minimal $10^{6} \mathrm{CFU} / \mathrm{mL}^{14}$

Pengujian aktivitas dilakukan dengan metode difusi agar atau sumur. Metode difusi agar didasarkan pada kemampuan senyawa-senyawa antibakteri yang diuji untuk menghasilkan jari-jari zona penghambatan di sekeliling sumur uji terhadap bakteri penguji. Diameter daerah hambat (DDH) yang terbentuk diukur dengan menggunakan jangka sorong pada masing-masing konsentrasi. Berikut hasil daya hambat yang terjadi pada minuman probiotik sari ubi kayu terhadap pertumbuhan bakteri Escherichia coli yang dapat dilihat pada Tabel 2 . 
Tabel 2. Hasil uji aktivitas minuman probiotik sari ubi kayu terhadap bakteri Escherichia coli

\begin{tabular}{lcc}
\hline Perlakuan & $\begin{array}{c}\text { Rata-rata } \\
\text { DDH (mm) }\end{array}$ & $\begin{array}{c}\text { Respon } \\
\text { Hambatan }\end{array}$ \\
\hline Kontrol (-) & 0 & $\begin{array}{l}\text { Tidak ada } \\
\text { hambatan } \\
\text { Kuat }\end{array}$ \\
Kontrol (+) & 15,06 & Sedang \\
Kultur 50:50 & 5,33 & \\
\hline
\end{tabular}

Berdasarkan Tabel 2 dapat dinyatakan bahwa hasil pengamatan yang diperoleh dari berbagai diameter daya hambat (DDH) yang terbentuk dari perbandingan kultur 50:50 menunjukan bahwa minuman probiotik sari ubi kayu memiliki aktivitas antibakteri dimana semakin luas zona bening yang terbentuk, maka semakin besar juga aktivitas yang terdapat pada sampel tersebut dan hal ini bukan berasal dari pelarut yang digunakan. Zona bening yang terbentuk dipengaruhi oleh bakteri asam laktat yang memproduksi asam laktat, asam-asam organik lain, hidrogen peroksida, dan diasetil serta senyawasenyawa lain yang bersifat antibakteri. ${ }^{20}$ Bakteri Lactobacillus dapat menurunkan $\mathrm{pH}$ lingkungan dengan mengubah gula menjadi asam laktat. Kondisi ini akan menghambat pertumbuhan beberapa jenis bakteri patogen.

\section{KESIMPULAN}

Perbandingan kultur bakteri dengan sari ubi kayu 50:50 terpilih sebagai perlakuan terbaik yang menghasilkan minuman probiotik sari ubi kayu dengan karakteristik pH 4,1; viskositas 0,706 $\mathrm{g} / \mathrm{mL}$; total bakteri asam laktat (BAL)

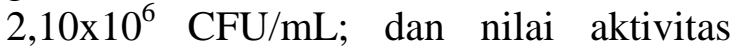
antibakteri terbesar terhadap bakteri Escherichia coli yaitu 5,33mm.

\section{UCAPAN TERIMA KASIH}

Ucapan terima kasih disampaikan kepada Kementerian Kesehatan yang telah memberikan dana penelitian ini melalui Dipa Poltekkes Kemenkes Tasikmalaya tahun 2019 dan Unit Penelitian dan Pengabdian pada Masyarakat Politeknik Kesehatan Kemenkes Tasikmalaya yang telah memfasilitasi penelitian ini.

\section{DAFTAR RUJUKAN}

1. Wiardani NI, Sugiani PP, Gumala NM. Konsumsi lemak total, lemak jenuh, dan kolesterol sebagai faktor risiko sindroma metabolik pada masyarakat perkotaan di Denpasar. Jurnal Gizi Klinik Indonesia. 2011;7(3):121-28.

2. Herlina E, Nuraeni. Pengembangan produk pangan fungsional berbasis ubi kayu (Manihot esculenta) dalam menunjang ketahanan pangan. Jurnal Sains Dasar. 2014;3(2):142-48.

3. Yuniastuti A. Buku monograf probiotik (Dalam Perspektif Kesehatan). Semarang: Unnes Press; 2014.

4. Widiyaningsih EN. Peran robiotik untuk kesehatan. Jurnal Kesehatan. 2011;4(1):14-20.

5. Nuranasari I. Potensi probiotik Lactobacillus yang diisolasi dari bakteri asam laktat hasil fermentasi kefir "gedono" dan viabilitasnya pada daging ayam olahan [skripsi]. Semarang: Unika Soegijapranata; 2015.

6. Kamara DS, Rachman SD, Pasisca RW, Djajasoepena S, Suprijana O, Idar I, Ishmayana S. Pembuatan dan aktivitas antibakteri yogurt hasil fermentasi tiga bakteri (Lactobacillus bulgaricus, Streptococcus thermophilus, Lactobacillus acidophilus). Al Kimia. 2016;4(2) :22-32.

7. Rizal S, Erna M, Nurainy F, Tambunan AR. Karakteristik probiotik minuman fermentasi laktat sari buah nanas dengan variasi jenis bakteri asam laktat. Jurnal Kimia Terapan Indonesia. 2016;18(1): 6371.

8. Rizal S, Marniza, Nurainy F. Pemanfaatan kulit nanas pada pembuatan minuman probiotik dengan jenis bakteri asam laktat berbeda. Prosiding Seminar nasional Sains dan teknologi VI; 2015 Nov 3; Bandar Lampung, Indonesia. Lampung: Lembaga Penelitian dan Pengabdian Universitas Lampung; 2015.p.459-73.

9. Suharyono AS, Rizal S, Nurainy F. Karakteristik minuman sinbiotik dari ekstrak daun cincau hijau (Premna 
oblongifolia Merr.) dengan konsentrasi sukrosa dan susu skim yang berbeda. Prosiding Seminar Nasional Sains MIPA dan Aplikasinya; 2009 Nov 16-17; Bandar Lampung, Indonesia. Lampung: Fakultas MIPA Universitas Lampung; 2009.p.895904.

10. Khotimah K, Kusnadi J. Aktivitas antibakteria minuman probiotik sari kurma (Phoenix dactilyfera, L.) menggunakan Lactobacillus plantarum dan Lactobacillus casei. Jurnal Pangan dan Agroindustri. 2014; 2(3):110-20.

11. Oktaviani EP, Purwijantiningsih LME, Pranata FS. Kualitas dan aktivitas antioksidan minuman probiotik dengan variasi ekstrak buah naga merah (Hyloreceus polyrhizus). Jurnal Teknobiologi. 2014;1(1):1-15.

12. Sandi YT, Zubaidah E. Pembuatan sake berbasis ubi kayu (Manihot esculanta crantz) kajian pengaruh konsentrasi starter saccharomyces cereviceae)". Jurnal Pangan dan Agroindustri. 2014; 2(4):1-9.

13. Retnowati PA, Kusnadi J. Pembuatan minuman probiotik sari buah kurma (Phoenix dactylifera) dengan isolat Lactobacillus Casei dan Lactobacillus plantarum. Jurnal Pangan dan Agroindustri. 2014; 2(2):70-81.

14. Fadhilah AN, Hafsan, Nur F. Penurunan kadar kolesterol oleh bakteri asam laktat asal dangke secara in vitro. Prosiding
Seminar Nasional Mikrobiologi Kesehatan dan Lingkungan; 2015 Jan 29; Makassar, Indonesia. Makassar: UIN Alauddin; 2015.p.174-80.

15. Vinderola G, Ouwehand A, Salminen S, Wright AV. Lactic acid bacteria: microbiological and functional aspects. Francis : CRC Press. 2019.

16. Efendi Z, Surawan FED, Winarto. Efek blanching dan metode pengeringan terhadap sifat fisikokimia tepung ubi jalar orange (Ipomoea batatas L.). Jurnal Agro Industri. 2015;5(2):109-17.

17. Maryana D. Pengaruh penambahan sukrosa terhadap jumlah bakteri dan keasaman whey fermentasi dengan menggunakan kombinasi Lactobacillus plantarum dan Lactobacillus acidophilus [skripsi]. Makassar: Universitas Hasanuddin; 2014.

18. Handayani I, Sustriawan B. Potensi Lactobacillus acidophilus dan Lactobacillus plantarum untuk menurunkan kolesterol pada minuman probiotik okara. Jurnal Pembangunan Pedesaan. 2012; 12(1):56-64.

19. Fardiaz S. Mikrobiologi pangan. Jakarta: Gramedia Pustaka Utama; 2014.

20. Singha TK. Microbial extracellular polymeric substances: production, isolation and applications. IOSR J Pharm. 2012;2(2):271-81. 